\title{
THE GLASSIGAL
}

\section{QUARTERLY \\ sarts ox}

K. J. DOVER, M.A.

E. J. KENNEY, M.A.

\author{
BOARD OF MANAGEMENT \\ PROP. E. H. WARMINGTON, M.A. (Chairman) \\ PROP. R. G. AUSTIN, M.A., D.LITT. (Hon. Treas.) \\ F. H. SANDBACH, M.A. \\ PROP. F. W. WALBANK, M.A., F.B.A. \\ PROF. W. S. WATT, M.A. \\ Representing the Council of the Classical Association
}

A. G. WOODHEAD, M.A., F.s.A., representing the Cambridge Philological Society R. G. M. NISBET, M.A., representing the Oxford Philological Society

With the co-operation of PROF. B. D. ME R IT T, Institute for Advanced Study, Princeton

PROF. J. A. FITZHERBERT, University of Adelaide

and PROP. HOMER A. THOM PSON, Institute for Advanced Study, Princeton

\author{
NEW SERIES - VOLUME XIII \\ (Volume LVI of the continuous series)
}

OXFORD - AT THE GLARENDON PRESS

I 963 
Oxford University Press, Amen House, London E.C. 4 GLASGOW NEW YORK TORONTO MELBOURNE WELLINGTON BOMBaY GaLcUTTA MADRAS KaRACHI LAHORE DACCA CAPE TOWN SALIBBURY NAIROBI IBADAN ACGRA KUALA LUMPUR HONG KONG

(C) Oxford University Press 1963

\section{I..ANCHESTEA \\ UNIVERSITY \\ LIBRARY}




\section{CONTENTS}

NUMBER I

Two Linguistic Topics in Quintilian

The Origin and Use of $O, H, T O \triangle E I N A$

Democritus, Fragment 156

ROBERT GOLEMAN

A. C. MOORHOUSE Ig

'Friendship' and 'Self-Sufficiency' in Homer and Aristotle W. I. MATSON 26

ARTHUR W. H. ADKINS 30

Stichos and Stanza

A. M. DALE 46

A Fragment of Sappho Reinterpreted

G. S. KIRK 5 I

A Paean in the Philoctetes

J. A. HALDANE 53

On Nicander, Oppian, and Quintus of Smyrna

M. L. WEST

Emendations and Interpretations in Nonnus' Dionysiaca

57

Virgil's Theodicy

GIUSEPPE GIANGRANDE 63

Crater Cratera Creterra

L. P. WILKINSON 75

L.S.J. and Cicero's Letters

WENDELL CLAUSEN

Enniana V

D. R. SHACKLETON BAILEY

O. SKUTSCH

A Note on $" A \Theta I I .22$

CHARLES W. FORNARA

Spartan Relations with Persia after the King's Peace: A Strange Story in Diodorus I 5.9

T. T. B. R Y DER

The Alleged Secret Pact between Athens and Philip II concerning

Amphipolis and Pydna

G. E. M. DE SAINTE GROIX

Demosthenes' Policy after the Peace of Philocrates. I

G. L. CAWKWELL I 20

Greek Precedents for Claudius' Actions in A.D. 48 and later

M. S. S M ITH

139

NUMBER 2

Two Lines of Eumelus

C. M. BOWRA 145

Three Presocratic Cosmologies

A Note on Aeschylus, Choephori 205 ff.

M. L. WEST

I 54

Notes on Euripides' Supplices

WALTER BURKERT

177

Sun, Line, and Cave Again

C. COLLARD

178

Two Points in Plato's Penal Code

JOHN FERGUSON

r 88

Demosthenes' Policy after the Peace of Philocrates. II

G. L. CAWKWELL 200

On The Interpretation of Aristotle, De Interpretatione I 2-I 3 R. S. B L UCK 2 I4

Forms of Individuals in Plotinus

JOHN M. RIST

An Alleged Fragment of Eunapius

ALAN D. E. CAMERON

223

232

Athenian Foreign Policy and the Peace-Conference at Sparta in 37 I B.C.

T. T. B. RYDER

237

The Commentarialum Petitionis

J. P. V. D. BALSDON

Cleopatra as Fatale Monstrum (Horace, Carm. I. 37. 2 I) J. V. LUCE

Vinnius Valens, Son of Vinnius Asina?

M. J. MCGANN

242

$25 \mathrm{I}$

258

The Hylas Episode in Valerius Flaccus' Argonautica

R. W. GARSON

260

A Note on the Mutiny of the Pannonian Legions in A.D. 14

J. J. WILKES 268

The Status Nomenclature of the Imperial Freedmen

P. R. G. WEAVER

272

Indexes

279 
The Publishers acknowledge with gratitude a generous grant from the British Academy towards the cost of this volume 